\title{
Funkcjonowanie szarej strefy w warunkach restrukturyzacji gospodarki
}

Transformacja struktur przemysłowych w procesie przechodzenia do gospodarki rynkowej to nie tylko strategia dywersyfikacji, czyli rozszerzenia produkowanego asortymentu. Proces transformacji w krajach postsocjalistycznych to restrukturyzacja całej gospodarki, która w dużej mierze zależy od zmian politycznych.

Środowisko ekonomiczne państwa charakteryzuje się strukturą jego gospodarki i proporcją dystrybucji dochodów. Według struktury gospodarki zachodni autorzy dzielą państwa na cztery typy:

- państwa o gospodarce naturalnej;

- państwa - eksporterzy surowców;

- państwa rozwijające się;

- państwa przemysłowo rozwinięte.

Nie wnikając w szczegóły tego podziału warto zaznaczyć, że podział ten nie jest wyczerpujący. Powinien być uzupełniony jeszcze jednym typem, mianowicie: państwa z gospodarką w okresie transformacji. Należy zaznaczyć, że proces przekształcania gospodarki centralnie sterowanej w gospodarkę rynkową we wszystkich państwach postsocjalistycznych przebiega bardzo boleśnie. Procesowi przekształceń towarzyszą różne negatywne zjawiska, rozmaite nadużycia i nieuczciwa działalność, które określa się jako szara strefa.

Według kryterium proporcji dystrybucji dochodów wyróżnia się natomiast pięć rodzajów państw:

- państwa z bardzo niskim poziomem dochodów rodzinnych;

- państwa z dominująco niskim poziomem dochodów rodzinnych;

- państwa z bardzo niskim i bardzo wysokim poziomem dochodów rodzinnych;

- państwa z niskim, średnim i wysokim poziomem dochodów rodzinnych;

- państwa z dominującym średnim poziomem dochodów rodzinnych.

Występowanie szarej strefy w gospodarce państwa prowadzi nie tylko do zburzenia istniejącego systemu dystrybucji dochodów rodzinnych, ale może także doprowadzić do upadku całej gospodarki narodowej. To samo można powiedzieć o środowisku kulturalnym w państwie. Spadek dochodów ludności nie sprzyja rozwojowi kultury. 
Środowisko kulturalne traci więc z powodu występowania szarej strefy i nie trzeba tego udowadniać danymi statystycznymi.

Środowisko polityczno-prawne z punktu widzenia badań marketingowych określa się następującymi czynnikami:

- stosunkiem państwa do zakupu towarów za granica;

- stabilnością polityczną w państwie;

- ograniczeniem dewizowym w państwie;

- rodzajem aparatu państwowego.

Właśnie te czynniki, a szczególnie ostatni, przyczyniają się do rozwoju szarej strefy

w skali całego państwa. Spróbujmy więc zapoznać się bardziej szczegółowo z tym zjawiskiem, które obejmuje nie tylko aspekty społeczne, ale w pierwszej kolejności polityczne.

Z punktu widzenia prawnego działalność gospodarczą można podzielić na działalność oficjalną i działalność nieoficjalną, określaną obecnie jako szara strefa. Działalność oficjalna - to działalność dozwolona układem prawnym państwa, a szara strefa to działalność, która przez prawo jest zabroniona. Mimo że działalność niektórych osób prawnych czy prywatnych z punktu widzenia zdrowego rozsądku można uznać za uczciwa, to jednak jeśli działalność ta wykracza poza ramy prawne, to jest traktowana przez władze administracyjne jako szara strefa. Polityka ekonomiczna państwa, a w jej wyniku całe środowisko społeczno-gospodarcze, jest więc kształtowana przez system prawny. Społeczeństwo jest dalekie od doskonałości, w każdym państwie istnieje więc działalność zabroniona przez prawo, szczególnie w sferze gospodarki. Wszystko to jest szarą strefą. Zasięg działalności szarej strefy w stosunku do działalności oficjalnej określa charakter ogólnego stanu gospodarki narodowej.

Działalność ekonomiczna jakichkolwiek podmiotów w społeczeństwie oceniana jest wg dwóch kryteriów: moralno-etycznych i administracyjnych (prawnych).

Kryteria moralno-etyczne gruntują się na ocenie działalności ekonomicznej podmiotów (struktur i/lub oddzielnych obywateli) z pozycji stycznych znanych każdemu obywatelowi i dominujących $\mathrm{w}$ danym społeczeństwie. Na wszystkich etapach historycznego rozwoju społeczeństwa najpotężniejszym z kryteriów moralno-etycznych były i pozostały kryteria religijne (zakaz oszustwa, kradzieży, zabójstwa i innych czynów niezgodnych z moralnością religijna). Do kryteriów religijnych można dołączyć także kryteria wynikające z założeń i obyczajów etnicznych, narodowych, wspólnotowych, które $\mathrm{w}$ swoich zasadach propaguja pewne postawy moralne dotyczące określonego spo-łeczeństwa. Dlatego, teoretycznie, istnienie szarej strefy nawet w najmniejszym stopniu nie byłoby możliwe, gdyby ludność przestrzegała wszystkich zasad moralno-etycznych, ponieważ działalność tej strefy nie jest możliwa bez oszustwa, kłamstwa, kradzieży, rabunku i innych amoralnych czynów. Pod tym względem kryteria moralno-etyczne, jakie formowały się $\mathrm{w}$ świadomości społeczeństwa w ciągu wielu pokoleń, są naturalnym hamulcem dla szarej strefy. Naturalne wydaje się więc, że każdy rząd w cywilizowanym państwie powinien być zainteresowany dostrzeganiem tych kryteriów, ponieważ buduje to podstawy dla rozwoju zdrowego społeczeństwa.

Ponieważ kryteria administracyjne występują w kształcie kompleksu układów czynnych, kompleks układów prawnych opiera się na kryteriach moralno-etycznych, uzupełnionych szeregiem dodatkowych ograniczeń, wywoływanych różnymi przyczy- 
nami, z których główną jest konieczność chronienia istniejących struktur państwa. I tu zaczynają się problemy. Trzeba zauważyć, że im więcej dodatkowych ograniczeń administracyjnych $w$ państwie, tym większe prawdopodobieństwo ich przekraczania. A każde przekroczenie tych ograniczeń traktuje się teoretycznie jako szarą strefę. Opierając się na definicji szarej strefy jako każdej działalności ekonomicznej, która jest nieuczciwa, zabroniona, niezarejestrowana i nieopodatkowana, trzeba zaznaczyć, że z punktu widzenia administracyjnego wszystko, co związane jest $\mathrm{z}$ działalnością niezarejestrowana, od razu traktowane jest jako zabronione. W takim thumaczeniu szarej strefy jest dużo punktów do wyjaśnienia w sprawie kwestii, czego rząd zabrania, a na co zezwala. To znaczy, że rząd może zabraniać tego, czego zabraniają kryteria moralno-etyczne, a nawet więcej, i traktować wykroczenia dużo ostrzej. Rząd może też wzbraniać tego, czego nie zabraniają kryteria moralno-etyczne, albo na odwrót wspierać działania, które według tych kryteriów są zabronione.

Z punktu widzenia obywatela takie czyny, jak handel narkotykami, handel bronią czy prostytucja są nieuczciwe i powinny być zabronione. Kryteria administracyjne i moralno-etyczne jednakowo traktują te czyny (chociaż trzeba na marginesie zaznaczyć, że zdarzają się w ostatnim czasie przypadki, że rząd oficjalnie zabrania handlu narkotykami, a sam zajmuje się nim na skalę międzynarodową). Jednak do szarej strefy rząd zalicza nie tylko działalność nieuczciwą z punktu widzenia obywatela, ale każdą działalność zabronioną przez prawo. Na przykład praca pojedynczych rzemieślników nie jest traktowana jako działalność nieuczciwa ani wg kryteriów moralno-etycznych, ani administracyjnych. Jednak gdy jest zbyt wysoko opodatkowana, to obywatel, chociażby dla wyżywienia się, a nie wzbogacenia, zmuszony jest ukrywać swoje dochody. A to jest już zabronione wg kryteriów administracyjnych i traktowane jako szara strefa. Wynika

$\mathrm{z}$ tego, że kryteria administracyjne i moralno-etyczne nie zawsze są zgodne.

Jeśli kryteria administracyjne oparte są na kryteriach moralno-etycznych, wtedy społeczność przyjmuje je z aprobatą i pochwala. Na przykład surową karę za drobne przestępstwa społeczeństwo traktuje jako obronę samej społeczności. Walka z szarą strefą jest wtedy efektywna, a przekroczenie przepisów prawnych dotyczy tylko marginesu społeczeństwa. Natomiast w przypadku, gdy kryteria administracyjne zabraniaja dużo więcej niż kryteria moralno-etyczne (np. surowy zakaz produkcji wyrobów tytoniowych czy alkoholowych), to chociaż społeczeństwo przyjmuje je na ogół neutralnie, skuteczność walki ze zjawiskami, które rząd traktuje jako szarą strefę, nie jest już tak wysoka jak w pierwszym przypadku, ponieważ społeczeństwo uważa te działania za obronę samego rządu, a nie społeczeństwa. W takim wypadku możliwości pojawienia się szarej strefy są większe. Kiedy kryteria administracyjne zabraniają wiele więcej i traktują wykroczenia dużo ostrzej niż kryteria moralno-etyczne, społeczeństwo naturalnie sprzeciwia się im, traktując je jako nieuczciwe, tym bardziej jeśli równolegle postrzega się zubożenie ludności. Ten sprzeciw społeczeństwa wywołuje wzrost szarej strefy jako samoobrony obywateli wobec takich zakazów. Wtedy nawet działalność uczciwa przenosi się szarej strefy, a skuteczność walki ze zjawiskami odnoszącymi się do tej strefy jest niska.

Jednocześnie warto zauważyć, że taka sytuacja trwa krótko, ponieważ szara strefa rozszerza się bardzo szybko na różne branże gospodarki, zwłaszcza na przemysł. Dla 
prostego obywatela szara strefa przestaje już być ratunkiem, ale zaczyna w sposób zorganizowany pochłaniać wszystkie sfery działalności gospodarczej.

Zdarzają się sytuacje, kiedy kryteria administracyjne przeciwstawiają się kryteriom moralno-etycznym, co wywołuje ostry sprzeciw społeczeństwa. W takim wypadku społeczeństwo ocenia działalność rządu jako wymierzoną przeciwko narodowi. Jasne jest, że walka z szarą strefą w takim przypadku nie jest skuteczna. W ten sposób stosunek kryteriów administracyjnych do moralno-etycznych daje przesłanki do powstania i rozwoju w państwie szarej strefy.

Poziom szarej strefy można określić współczynnikiem strefy szarej $\left(\mathrm{W}_{\mathrm{ss}}\right)$, rozumianym jako stosunek produktu szarej strefy brutto do produktu krajowego brutto (oficjalnego i szarej strefy). Wyliczenie tego współczynnika jest możliwe, ale w dużym stopniu będą to dane przybliżone, gdyż dokładne dane w statystyce dotyczą tylko oficjalnego produktu krajowego brutto. Produkt szarej strefy może być tylko w przybliżeniu oszacowany.

Na podstawie wyliczeń tego współczynnika rozwój szarej strefy w państwie można podzielić na następujące etapy:

1. Szara strefa lokalna, charakteryzująca się współczynnikiem ok. $0,1\left(\mathrm{~W}_{\mathrm{ss}}<0,1\right)$. Przy takim poziomie szarej strefy można przyjąć, że stan gospodarki państwa jest dobry, gdyż nie ma kraju, w którym nie byłoby przestępstw gospodarczych, chociażby w minimalnym stopniu (ktoś uchyla się od spłaty podatków, ktoś coś ukradł itp.). Sytuacja ekonomiczna państwa jest więc pomyślna, o ile nie ma podstawy do dalszego rozwoju szarej strefy.

2. Szara strefa przenikająca, określana wartością współczynnika od 0,1 do 0,2 $\left(0,1<\mathrm{W}_{\mathrm{ss}}<0,2\right)$. Na takim etapie rozwoju tej strefy zaczynają się rozbieżności pomiędzy kryteriami administracyjnymi i moralno-etycznymi, wzrasta fiskalizm, a ludność zaczyna (tylko zaczyna) okazywać negatywny stosunek do polityki ekonomicznej państwa, widząc w zabronionym działaniu, szansę na obronę swojej sytuacji ekonomicznej. Jednocześnie rozpoczyna się proces wkraczania szarej strefy do oficjalnych kół gospodarczych. Etap przenikającej strefy szarej jest krótkotrwały. Na tym etapie zaczyna się organizować przestępczość ekonomiczna jako składowa ogólnej kryminalizacji społeczeństwa. Kapitał narodowy ucieka za granicę, pogarsza się natomiast klimat inwestycyjny dla kapitału zagranicznego.

3. Szara strefa aktywna, charakteryzująca się współczynnikiem w granicach od 0,2 do $0,4\left(0,2<\mathrm{W}_{\mathrm{ss}}<0,4\right)$. Obejmuje większość branż gospodarki oficjalnej i - co najbardziej bolesne - branżę produkcyjną. Przy aktywnej strefie szarej korupcja administracyjnego aparatu państwowego wzrasta do takiego stopnia, że kryteria administracyjne tworzone tym aparatem prawie całkowicie przeciwstawiają się kryteriom moralno-etycznym, chociaż oficjalnie o tym nikt nie wspomina. Jednocześnie fiskalizm państwa jest tak potężny, że społeczeństwo na ogół przeciwstawia się kryteriom administracyjnym.

4. Przy współczynniku powyżej $0,4\left(\mathrm{~W}_{\mathrm{ss}}>0,4\right)$ szarą strefę określa się jako totalną. Państwowy aparat administracyjny łączy się ze strukturami kryminalnymi, prowadząc do nieuczciwej dystrybucji budżetu państwowego. Taki etap charakteryzuje się deformacją systemu dystrybucji w państwie, kryminalizacją środowiska społecznego i totalną nieściagalnością podatków. 
Będąc sposobem socjalnej samoobrony $\left(\mathrm{W}_{\mathrm{ss}}\right.$ ok. 0,2) szara strefa jako wynik kryzysu ekonomicznego przy współczynniku ok. 0,4 i więcej staje się przyczyną dalszego wzrostu kryzysu. Większość przedsiębiorstw legalnych, w tym wielkich przedsiębiorstw państwowych, omija płacenie podatków, utajając wielkość swojej produkcji i tym

samym podpadając pod określenie szarej strefy. Wszelkie kryteria administracyjne społeczeństwo prawie całkowicie traktuje jako nieuczciwe i amoralne, jednocześnie oczekując zmian w sytuacji ekonomicznej, choćby nawet przy pomocy nowych, ostrzejszych zakazów administracyjnych, ponieważ okazuje się, że szara strefa nie jest oczekiwanym wybawieniem od ogólnego zubożenia.

Sytuacja, w której znajduje się państwo z szarą strefą na poziomie aktywnym, nie mówiąc już o totalnym, powoduje niemożliwość prowadzenia działalności marketingowej. Przeprowadzając ocenę sytuacji ekonomicznej w państwie z punktu jego analizy marketingowej jako potencjalnego rynku międzynarodowego, można dojść do wniosku, że już przy wzroście wymienionego współczynnika powyżej 0,2 wszelkie programy marketingowe zaczynają tracić sens. Zaczyna zanikać konkurencja. Dlatego cechy, jakość, opakowanie, markę, serwis, gwarancję i zwroty towarów dyktuje nie rynek, a monopolista. On także dyktuje cenę. Polityka cenowa jako instrument programu marketingowego staje się więc nieaktualna. Polityka dystrybucji coraz bardziej koncentruje się w rękach monopoli.

Na pierwszym etapie restrukturyzacji gospodarki zauważa się, że patrząc w przyszłość potężne firmy dla zagarnięcia rynku zamiast promocji stosują ceny dumpingowe. $\mathrm{Z}$ drugiej strony wskutek zubożenia społeczeństwa coraz bardziej zmniejsza się koło potencjalnych odbiorców, a szara strefa przenikając w aparat administracyjny przyczynia się do upadku małych firm i przedsiębiorstw.

Wszystko to ocenia się przy pomocy metody analizy marketingowej państwa jako potencjalnego rynku międzynarodowego, a także jako obiektu potencjalnych inwestycji.

Sytuacja socjalna w państwie całkowicie zależy od poziomu rozwoju szarej strefy, a ona $\mathrm{z}$ kolei jest produktem polityki państwowej. Od tego, jak rząd poradzi sobie z tą polityką, zależy proces przekształceń gospodarki, wprowadzenia stosunków wolnorynkowych i stan materialny społeczeństwa. 